Bangladesh J. Bot. 43(3): 315-321, 2014 (December)

\title{
ETHNOBOTANICAL ASPECTS OF SOME GEOPHYTES FROM ERGAN MOUNTAIN, TURKEY
}

\author{
Mustafa Korkmaz* Zennettin Alpaslan, Nevzat Turgut and Veli Ilhan \\ Department of Biology, Science and Art Faculty, Erzincan University, Erzincan-Turkey
}

Key words: Ergan mountain, Ethnobotany geophytes, Erzincan

\begin{abstract}
The genotypes of Ergan mountain, Erzican, Turkey were studied and documented. A total of 25 taxa belonging to 14 genera and 9 families have been collected in this study. Local name, used plant parts and the ethnobotanical uses of the geophyte - species were determined. Of the recorded taxa, $48 \%$ belonged to IranoTwianian phytogeographic region, $12 \%$ to Europe-Siberian region and $4 \%$ to Mediterranean region. Five taxa namely, Allium armenum Boiss. \& Kotschy, A. sintenisii Freyn, Muscentoiceleste Formin, Fritillaria pinardii Boiss. and Tulipa armena sbusp. Lyia (Baker) Marais recorded from the study area are endemic to Turkey.
\end{abstract}

\section{Introduction}

Turkey has been extremely rich in geophytes. There has been 540 geophyte plant species of 26 families in Turkish Flora (Özel and Erden 2010). Geophytes have been known well since the periods before Christ and have been commonly evaluated for medicinal, aromatic and ornamental purposes. The plants that have been benefited for public medicine since ancient times have also been benefited in modern medicine, as well (Özel and Erden 2010).

Eastern Anatolian Region has been the second most important region of Turkey in terms of floristic diversity. Erzincan province with a transition feature among Eastern Black Sea, Eastern Anatolia and Central Anatolia regions has been one of the important gene and endemism centers of Turkey. According to Davis (1965-1988), totally 795 species belonging to 87 families have been recorded in Erzincan and 276 of those are endemic. This number of endemic species has reached 437 in a recent study which has been carried out (Korkmaz et al. 2013).

The province of Erzincan with $11909 \mathrm{~km}^{2}$ surface area has largely been located in Yukar1 Firat sub-region of Eastern Anatolian Region and a part of Irano-Turanian phytogeographic region. Erzincan has had 2 out of 13 endemic plant centers and six important plant sites of Turkey (Şahin and Gök 2004).

Munzur Mountain, forming natural border between Erzincan and Tunceli has been one of the most important endemic centers of Turkey and run for $120 \mathrm{~km}$ in east-west direction. The highest point of the mountain is Akbaba hill $(3462 \mathrm{~m})$. The highest temperature $\left(41.3^{\circ} \mathrm{C}\right)$ is in July and the coldest in January with $-32.5^{\circ} \mathrm{C}$. Average annual rainfall is between 363.7 and $941.3 \mathrm{~mm}$. The climate of Munzur Mountains is semi-arid Mediterranean climate (Yıldırıml1 1995, Y1dırımlı and Erik 1985). Ergan Mountain, has taken place on nearly $20 \mathrm{~km}$ south of Erzincan. It has been located on the north-east part of Munzur Mountains. The map of the Ergan Mountain has been given in Fig. 1.

Özgen et al. (2012) and Polat et al. (2012) stated that the province of Erzincan was the one that has been studied the least in Eastern Anatolian Region. Except from flora of Munzur Mountains (Y1ldırıml 1995) no floristical and ethnobotanical studies have been carried out in the study area before.

*Author for correspondence: <korkmazmustafa67@yahoo.com.tr>. 


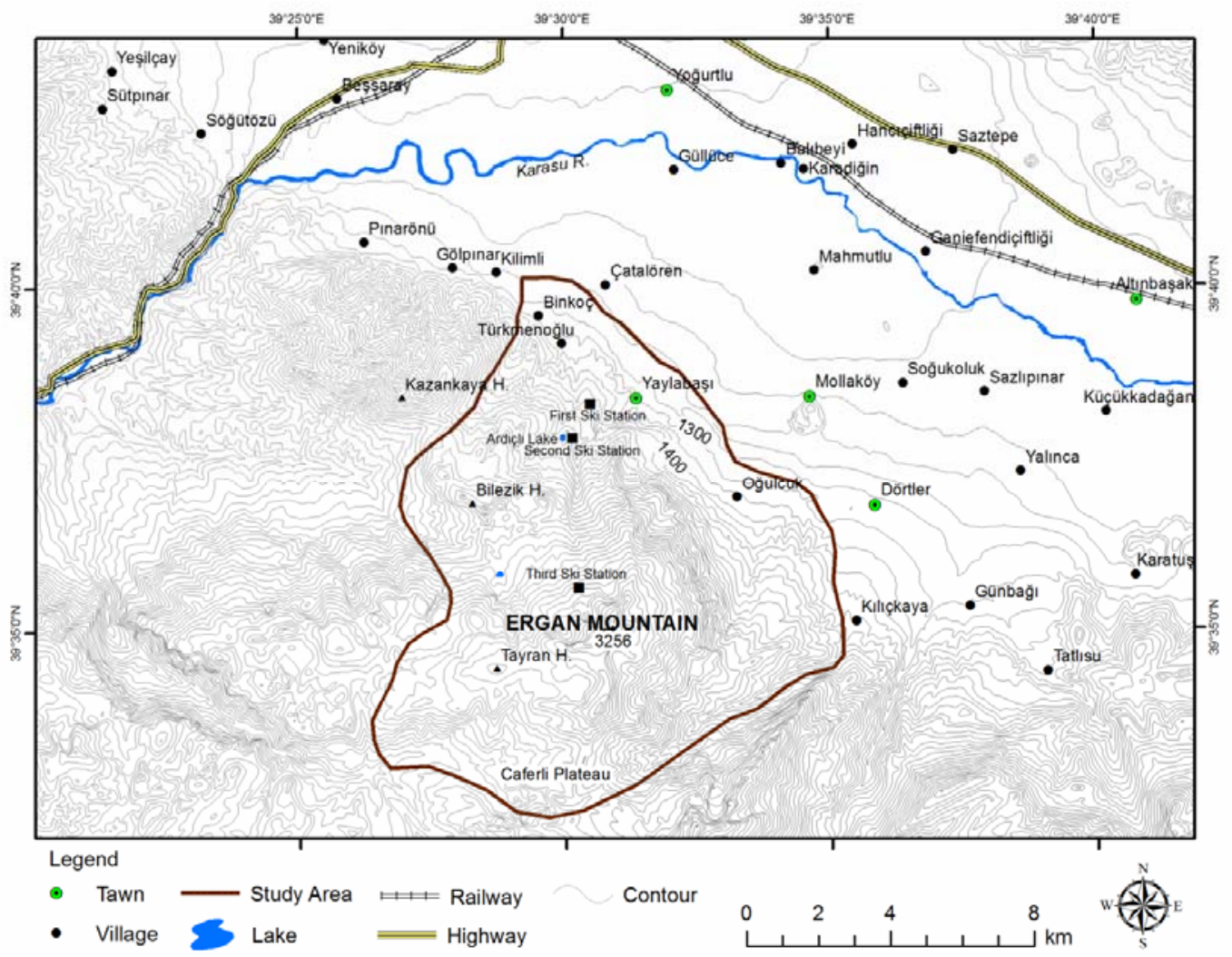

Fig. 1. The geographical map of the study area.

\section{Materials and Methods}

Plant samples were collected from Ergan Mountain in the spring and summer periods of 2011. The collected samples were pressed, and dried following standard herbarium techniques. The samples were identified by consulting Davis (1965-1988), Güner et al. (2000), Güner (2012). Help from the local Herberium was also taken for the identification.

Furthermore, the identification (or recording) of all the plant samples were controlled from Tubives (Turkish plants data service). Plant samples were preserved in Erzincan University, Faculty of Science and Art, Department of Biology Herbarium. Further, the identification (or recording) of all the plant samples were controlled from Tubives (Turkish plants data service). The ethnobotanical feature of each taxon was ascertained by consulting Koyuncu and Arslan ?(2009), Şimşek et al. (2004), Tuzlacı and Doğan (2010). Interest to the beral medicine by the local inhabitants were also considered.

\section{Results and Discussion}

Twenty five species belonging to 14 genera and 9 families were recorded. The species and their families along with the locality of collection and date of collection have been furnished in Table 1. However, their ethnobotanical properties are listed in Table 2. 
Table 1. List of the geophyte species collected from Ergan Mountain.

\section{Amaryllidaceae}

1. Allium armenum Boiss. \& Kotschy: Yaylabaş1 District, 28.07.2011, 491, Ir.-Tur., End.

2. Allium cardiostemon Fisch. \& Mey.: Binkoç village, 02.07.2011, 343, Ir.-Tur.

3. Allium decipiens Fischer ex Schultes \& Schultes fil.: Yaylabaşı District, 08.06.2011, 127; Oğulcuk village, 11.06.2011, 205, Eur.-Sib.

4. Allium kharputense Freyn \& Sint.: Binkoç village, 19.06.2011, 273, Ir.-Tur.

5. Allium scorodoprasum L. subsp. scorodoprasum: Yaylabaşı District, 11.07.2011, 397-b, Eur.- Sib., New record.

6. Allium sintenisii Freyn: Yaylabaşı District, 27.06.2011, 280; Yaylabaşı District, 11.07.2011, 397, Ir.-Tur., End.

\section{Asparagaceae}

7. Muscari armeniacum Leichtlin ex Baker: Oğulcuk village, 26.05.2011, 44; Binkoç village, 30.05.2011, 86.

8. M. coeleste Fomin: Yaylabaşı District, 21.04.2011, 4; Yaylabaş1 District, 09.06.2011, 142, Ir.-Tur., End.

9. M. tenuiflorum Tausch: Erzincan: Yaylabaşı District, 08.06.2011, 94; Yaylabaşı District, 09.06.2011, 177; Binkoç village, 02.07.2011, 312 .

10. Ornihogalum oligophyllum E.D. Clarke: Binkoç village, 30.05.2011, 56; Yaylabaşı District, 09.06.2011, 147.

11. O. sphaerocarpum Kerner: Binkoç village, 02.07.2011, 314.

12. Puschkineia scilloides Adams: Yaylabaşı District, 09.06.2011, 163, Ir.-Tur.?, New record.

13. Scilla siberica Haw. subsp. armena (Grossh.) Mordak: Yaylabaşı District, 21.04.2011, 2, Ir.-Tur.

\section{Geraniaceae}

14. Geranium tuberosum L. subsp. tuberosum: Yaylabaş1 District, 16.05.2011, 9; Oğulcuk village, 26.05.2011, 32; Binkoç village, 30.05.2011, 84; Yaylabaşı District, 09.06.2011, 166.

\section{Iridaceae}

15. Iris caucasica Hoffm. subsp. turcica B. Mathew: Yaylabaşı District, 16.05.2011, 16; Yaylabaşı District, 16.05.2011, 30; Binkoç village, 30.05.2011, 89; Oğulcuk village, 11.06.2011, 212, Ir.- Tur.

\section{Ixioliriaceae}

16. Ixiolirion tataricum (Pallas) Herbert subsp. montanum (Labill.) Takth.: Yaylabaşı District, 16.05.2011, 28, Ir.-Tur.

\section{Liliaceae}

17. Fritillaria pinardii Boiss.: Binkoç village, 30.05.2011, 88, Ir.-Tur., End.

18. Tulipa armena Boiss. subsp. lycica (Baker) Marais: Yaylabaşı District, 16.05.2011, 13, End.

19. T. julia C. Koch: Above of Oğulcuk village, 26.05.201, 45; Oğulcuk village, 11.06.2011, 200, Ir.-Tur.

\section{Orchidaceae}

20. Dactylorhiza iberica (Bieb. ex Willd.) Soo: Binkoç Village, 12.07.2011, 428, Medit.

21. D. umbrosa (Kar. \& Kir.) Nevski: above of Oğulcuk village, 18.06.2011, 233; Binkoç village, 19.06.2011, 263; Binkoç village, 02.07.2011, 319, Ir.- Tur.

22. Orchis coriophora L.: Yaylabaşı District, 09.06.2011, 175.

23. O. pallens L.: Yaylabaşı District, 16.05.2011, 10; Oğulcuk village, 26.05.2011, 38, Eur.-Sib.?

\section{Paeoniaceae}

24. Paeonia mascula (L.) Miller subsp. arietina (Anderson) Cullen \& Heywood: Yaylabaşı District, 08.06.2011, 125; Yaylabaşı District, 27.06.2011, 289.

\section{Xanthorrhoeaceae}

25. Eremurus spectabilis Bieb.: Oğulcuk village, 18.06.2011, 240; Yaylabaşı District, 27.06.2011, 293, Ir.-Tur. 


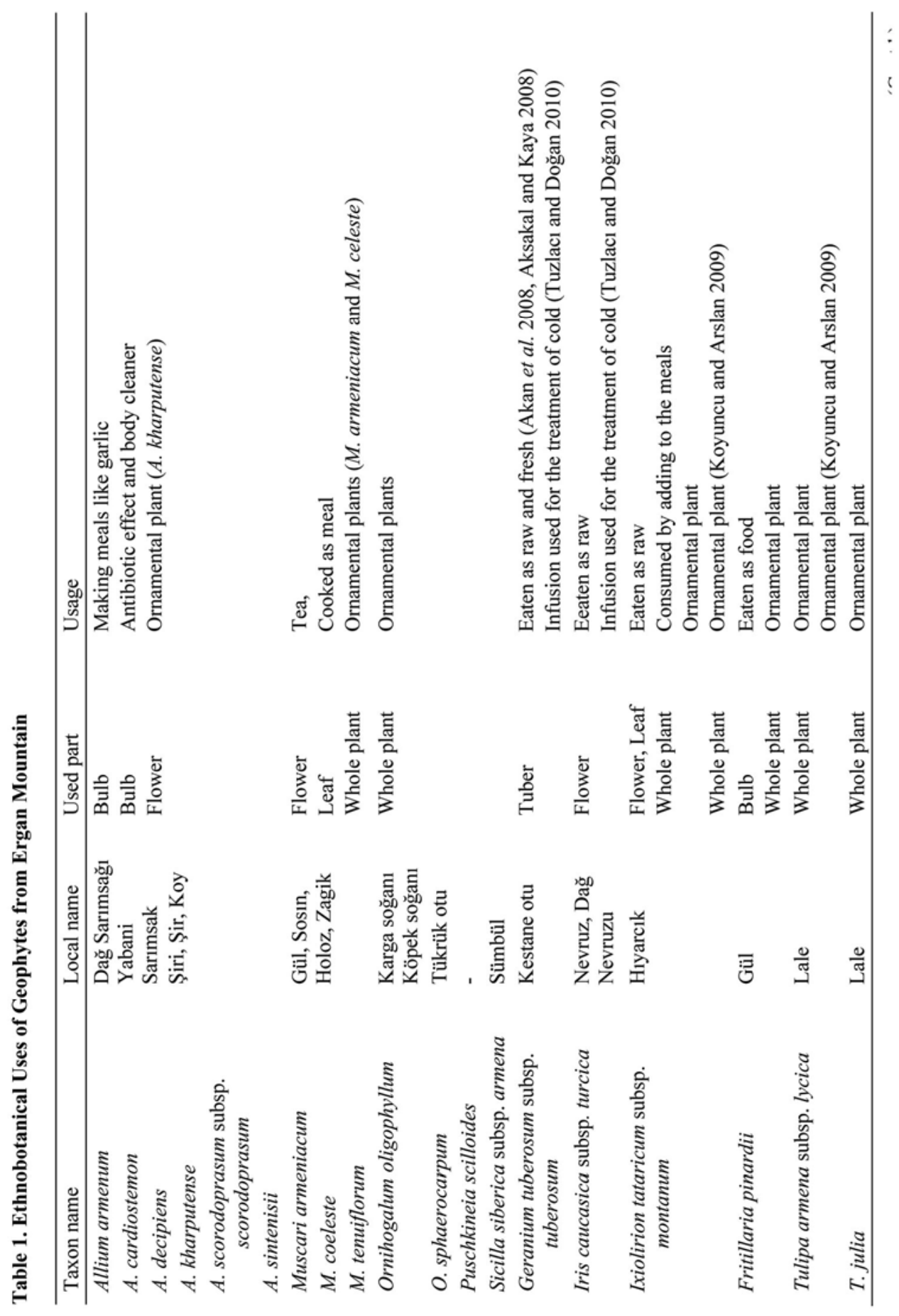




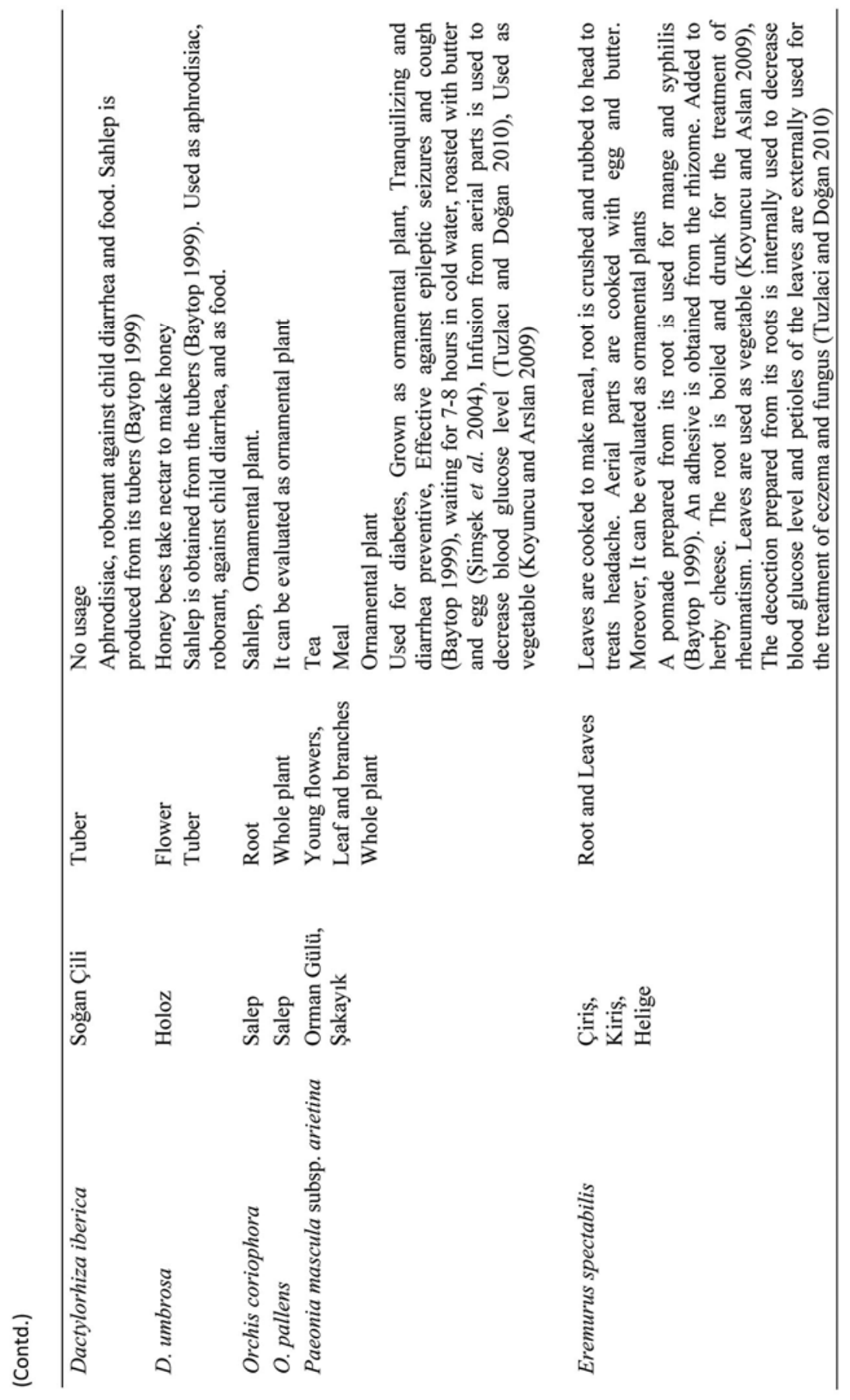


Among the geophyte species $48.0 \%$ belong to Irano-Turanian phytogeographic region, $12.0 \%$ to Europe-Siberian region and $4.0 \%$ to Mediterranean region. In addition, Allium scorodoprasum subsp. scorodoprasum and Puschkineia scilloides have been determined as a new record to B7 square. Five taxa (Allium armenum, A. sintenisii, Muscari celeste, Fritillaria pinardii and Tulipa armena subsp. lycia) found in the study area were determined as endemic to Turkey (Ekim et al. 2000).

All species collected from the study area have been found as having important ethnobotanical features (Table 1). A total of 16 taxa has been recognized as ornamental. Although use of the roots of Asphodeline tenuior subsp. tenuiflora var. tenuiflora was not encountered in the study area, according to Tuzlacı and Doğan (2010) it has been used for the treatment of scars.

Geophyte plants have created an important part of the species existing in natural flora of Turkey. According to this study, they have high potential to be used at medicine and ornamental planting and are important in terms of economy. Further studies should be carried out on the geophytes of the study area, especially to introduce them in the cultivation, so that they can more significantly contribute to the economy. They have been under the risk of many reasons such as land clearing, overgrazing, industrialization, agricultural pests, forest fires, road building works and export (Ekim et al. 1989). Constructional works for ski-run and ski-facilities have been been going on in Ergan Mountain areas. Besides, stock-breeding and grazing which are common in the province have also been recognized as the major threats to the rare and endemic geophyte plant species growing in the area. Stubble burning which has been found as common even in central villages of the province has been an essential factor that threatens the natural life and plant diversity. So, different conservation initiatives including the educational activities to increase the public inform public awareness should be implemented in the area for sustainable development.

\section{Acknowledgements}

The study is a part of a research project (KUDAKA-TRA1/10/TTS/01-016.) supported by the Prime Ministership of Turkish Republic. The relevant institution for financial support and the local people for extending their help to determine the traditional use of the plants are duly acknowledged and thanked.

\section{References}

Akan H, Korkut MM and Balos MM 2008. An ethnobotanical study around Arat Mountain and its surroundings (Birecik, Şanlıurfa). Science and Eng. J. of Firat Univ. 20 (1): 67-81.

Aksakal Ö and Kaya Y 2008. Plants used as food by people in and around Erzurum. pp.1009-1012. Türkiye $10^{\text {th }}$ Food Cong., 21-23 May., 2008. Erzurum.

Baytop T 1999. Türkiye'de Bitkiler ile Tedavi (Geçmişte ve Bugün). Nobel Tıp Kitabevleri, İstanbul.

Davis PH 1965-1985. Flora of Turkey and the East Aegean Islands. Vol. 1-9, Edinburgh Univ. Press, Edinburgh.

Davis PH (ed.), Mill RR and Tan K 1988. Flora of Turkey and the East Aegean Islands. Vol. 10, Edinburgh University Press, Edinburgh.

Ekim T, Koyuncu M, Erik S, İlarslan R 1989. Türkiye'nin Tehlike Altındaki Nadir ve Endemik Bitki Türleri. Türkiye Tabiatını Koruma Derneği Yayınları No. 18, Ankara.

Ekim T, Koyuncu M, Duman H, Aytaç Z and Adıgüzel N 2000. Red Data Book of Turkish Plants (Pteridophyta and Spermatophyta). The Council of Protecting the Turkish Nature Press, Ankara. 96 pp.

Güner A, Özhatay N, Ekim T and Baser KHC 2000. Flora of Turkey and the East Aegean Islands (supple. 2), Vol. 11, Edinburgh Univ. Press., Edinburgh. 
Güner A 2012. A Check List of the Flora of Turkey (Vascular Plants). Nezahat Gökyiğit Botanik Bahçesi Yayınları, Flora Dizisi 1, İstanbul.

Korkmaz M, Özçelik H, Kandemir A and İlhan V 2013. Natural Rose (Rosa L.) Taxa Distributed in Erzincan and Its Environs. Süleyman Demirel University Journal of Natural and Applied Sciences (In press).

Koyuncu M and Arslan N 2009. Munzur Vadisi'nin Biyolojik Çeşitliliğinin Korunması. Ulaşılabilir Yaşam Derneği, Ankara.

Özel A and Erden K 2010. Determination of capacity to produce marketable bulb and morphological characteristics of some exported geophytes. Harran Univ. J. Faculty of Agricul. 14(2): 90-99.

Özgen U, Kaya Y and Houghton P 2012. Folk medicines in the villages of Ilica district (Erzurum, Turkey). Turk. J. Biol. 36: 93-106.

Polat R, Çakılcığlu U, Ertuğ F and Satıl F 2012. An evaluation of ethnobotanical studies in Eastern Anatolia. Biol. Diver. and Conserv. 5(2): 23-40.

Şahin İF and Gök Y 2004. Bee-raising in Erzincan. Eastern Geographical Review 9(11): 7-30.

Şimşek I, Aytekin F, Yeşilada E and Yıldırımlı Ş 2004. An ethnobotanical study on the uses of plants amoung the people in Anatolia. Proceedings of the $14^{\text {th }}$ Symposium on Plant Originated Crude Drugs, Eskişehir.

Tuzlacı E and Doğan A 2010. Turkish folk medicinal plants, IX: Ovacık (Tunceli). Marmara Pharma. J. 14: 136-143.

Yıldırımlı Ş 1995. Flora of Munzur Dağları (Erzincan-Tunceli), OT Sistematik Botanik Dergisi 2(1): 1-78.

Yıldırımlı Ş and Erik S 1985. Main vegetation types of Munzur mountains, Doğa Bilim Dergisi A2 9(3): 598605. 